\title{
PENAMPILAN KARKAS AYAM PEDAGING DENGAN PEMBERIAN KULIT KOPI (Coffea sp) PENGOLAHAN SEDERHANA SUBSTITUSI SEBAGIAN JAGUNG DENGAN LEVEL YANG BERBEDA
}

\author{
Indriani Antarani, J.T. Laihad, Z. Poli, P.R.R.I. Montong
}

Fakultas Peternakan Universitas Sam Ratulangi Manado, 95115

\begin{abstract}
ABSTRAK
Penelitian ini bertujuan untuk mengkaji sejauh mana pengaruh pemberian limbah kulit kopi pengolahan sederhana substitusi sebagian jagung terhadap persentase bobot bagian-bagian karkas ayam pedaging yang meliputi paha, sayap, dada dan punggung. Penelitian ini menggunakan 144 ekor DOC (day old chicken) strain CP 707 tanpa membedakan jenis kelamin (unsexed). Penelitian ini menggunakan rancangan acak lengkap (RAL) pola faktorial $3 \times 4$ dengan 3 ulangan dimana setiap ulangan terdiri atas empat ekor ayam. Faktor A merupakan pengolahan kulit kopi dimana A1 yaitu kulit kopi yang dijemur, A2 kulit kopi yang direndam dan A3 kulit kopi yang direbus, sedangkan faktor B yaitu level substitusi kulit kopi terhadap jagung $\mathrm{B} 1=0 \%$, $\mathrm{B} 2=25 \%$, B3=50\% dan B4=75\%. Variabel yang diamati yaitu persentase bobot bagian-bagian karkas yang meliputi paha, sayap, dada dan punggung. Data yang didapat dianalisis dengan analisis keragaman (Anova) dan apabila berpengaruh nyata maka dilakukan uji lanjut beda nyata jujur (BNJ).

Berdasarkan hasil analisis keragaman menunjukan bahwa interaksi antara kulit kopi (A) jemur, rendam, rebus dengan level substitusi (B) memberikan pengaruh tidak berbeda nyata $(\mathrm{P}>0.05)$ terhadap persentase bobot paha, sayap, dada dan punggung. Hasil yang sama juga ditujukan oleh metode pengolahan kulit kopi (A) yang artinya jemur, rendam dan rebus tidak
\end{abstract}

*Korespondensi (corresponding author) Email: richard_montong@unsrat.ac.id memberikan pengaruh sedangkan, hasil yang berbeda ditunjukan oleh level subtitusi (B) dimana hasil analisis keragaman menunjukan pengaruh yang berbeda $(\mathrm{P}<0.05)$ terhadap persentase bobot dada. Persentase bobot bagianbagian karkas dalam penelitian ini yaitu bagian paha $28,92 \%-30,98 \%$, bagian sayap $10,38 \%-12,68 \%$, bagian dada $35,10 \%$ $38,55 \%$ dan bagian punggung $19,68 \%$ $22,71 \%$.

Dari hasil penelitian dapat disimpulkan bahwa penggunaan kulit kopi $25 \%$ menggantikan sebagian jagung memberikan hasil terbaik terhadap persentase bobot bagian-bagian karkas ayam pedaging pada semua metode pengolahan.

Kata kunci: Ayam Broiler, Bagian Karkas, Kulit Kopi

\section{ABSTRACT}

\section{CARCASS PERFORMANCE OF BROILER FED RATION CONTAINING COFFEE (Coffea sp) HUSK WASTE PRODUCT TREATED BY SIMPLE PROCESSING AND SUBSTITUTING PARTS OF CORN WITH DIFFERENT LEVELS. Broilers} had rapid growth rate and need high nutrient protein and energy balance in the diet. This study was conducted to evaluate the use of coffee husk waste product treated by simple processing substituted with part of corn in ration on carcass percentage of broiler. Study was applied at Faculty of Animal Science, Sam Ratulangi University during 35 days. Total of 144 day old chick unsexed broilers, strain of CP 707, 
involving 36 experimental units of battery pens were used in this study. Each unit of pen was filled 4 birds under completely randomized design on factorial patter of $3 \times 4$. Factor A was focused on three processing treatments including coffee husk heated under sun light (A1), coffee husk immersed in the water (A2), and coffee husk boiled under water (A3). Factor $B$ was focused on four treatments of substitution levels including ration containing corn without coffee husk substitution (B0), ration containing corn substituted with $25 \%$ coffee husk (B1), ration containing corn substituted with $50 \%$ coffee husk (B2), ration containing corn substituted with $75 \%$ coffee husk (B3). Variables observed were including percentages of thigh, wing, breast and back part.

Analysis of variance showed that interaction of processing treatments did not affect significantly on the percentages of thigh, wing, breast and back part. This study indicated that simple processing of coffee husk were not affected the carcass percentages of broiler. The substitution levels significantly affected carcass percentage of broiler. Percentages of thigh, wing, breast and back part were $28.92 \%$ $30.98 \%, 10.38 \%-12.68 \%, 35.10 \%-38.55 \%$ and $19,68 \%-22,71 \%$, respectively.

This study showed that utilization of coffee husk waste product by above simple processing could substitute part of corn in ration of $25 \%$ producing high carcass percentage of broiler.

Keywords: Coffee husk by product, broiler part of carcass percentage

\section{PENDAHULUAN}

Peningkatan produktivitas ternak ayam broiler baik mutu maupun kualitas daging dalam memenuhi kebutuhan konsumen mendorong peternak untuk dapat menghasilkan bobot karkas yang tinggi serta kualitas yang baik. Karkas ayam adalah bobot tubuh ayam setelah dipotong dikurangi kepala, kaki, darah dan bulu serta organ dalam. Kualitas serta bobot karkas dipengaruhi oleh faktor sebelum pemotongan, umur, jenis kelamin dan ransum serta proses setelah pemotongan.

Ransum merupakan salah satu faktor yang penting untuk menghasilkan kualitas maupun bobot karkas yang baik. Penggunaan sumberdaya lokal sebagai bahan penyusun ransum unggas telah banyak diteliti (Noferdiman, 2009; Uzer et al., 2013). Sumberdaya lokal yang banyak digunakan berasal dari limbah pertanian yang diolah sebelum dijadikan bahan penyusun ransum. Salah satu limbah yang bisa digunakan yaitu kulit kopi karena selain sumber serat kasar, kulit kopi juga memiliki kandungan energi serta protein yang cukup tinggi, harga relatif murah dan mudah didapat. Menurut Mayasari (2009) kulit kopi mengandung serat kasar berupa selulosa, hemiselulosa dan lignin yang sulit dicerna sehingga perlu adanya pengolahan. Adapun cara pengolahan sederhana yang bisa dilakukan yaitu dijemur, direndam, dan direbus guna untuk menurunkan kandungan serat kasar di dalamnya.

Keinginan konsumen berbeda-beda dalam memilih potongan bagian-bagian karkas ayam broiler, potongan bagianbagian ini dapat meningkatkan daya jual, 
karena selain sumber protein hewani, harga dari masing-masing potongan juga terjangkau. Bagian-bagian karkas adalah bagian dari karkas utuh yang telah dipotong-potong terdiri atas bagian paha, sayap dada dan punggung (BSN, 2009). Menurut Massolo et al. (2017) bagian dada merupakan potongan yang menjadi tolok ukur kualitas karkas ayam pedaging karena sebagian besar otot sebagai komponen karkas terdapat pada bagian ini. Pemotongan bagian-bagian karkas dapat meningkatkan daya jual, karena konsumen dapat dengan bebas memilih bagian mana yang disukai. Selain itu potongan bagianbagian karkas (ready to cook) juga dipilih karena lebih praktis dan siap untuk diolah.

Dari uraian di atas maka dilakukan penelitian tentang penampilan karkas ayam pedaging dengan pemberian kulit kopi pengolahan sederhana substitusi sebagian jagung dengan level yang berbeda dengan tujuan untuk mengkaji sejauh mana pengaruhnya terhadap persentase bobot bagian-bagian karkas paha, sayap, dada, dan punggung ayam pedaging.

\section{MATERI DAN METODE PENELITIAN}

Penelitian ini dilaksanakan selama bulan Agustus-Oktober 2018 selama 35 hari di kandang Fakultas Peternakan Universitas Sam Ratulangi Manado.
Ternak yang digunakan yaitu 144 ekor DOC (Day old chicken) strain Cobb, CP 707 tanpa membedakan jenis kelamin (unsex). Penelitian ini menggunakan rancangan acak lengkap (RAL) (Steel and Torrie, 1980) pola faktorial $3 \times 4$ dengan 3 ulangan, setiap ulangan terdiri atas empat ekor ayam. Faktor A merupakan ransum perlakuan kulit kopi pengolahan sederhana dimana A1 yaitu kulit kopi yang dijemur, A2 kulit kopi yang direndam dan A3 kulit kopi yang direbus, sedangkan faktor B yaitu level substitusi dimana B0 yaitu 0\% kulit kopi dalam ransum sebagai kontrol, B1 yaitu substitusi 25\% kulit kopi terhadap jagung, B2 yaitu substitusi 50\% kulit kopi terhadap jagung sedangkan B3 yaitu substitusi $75 \%$ kulit kopi terhadap jagung. Ayam umur 1-14 hari diberikan pakan komersial (AD1). Sebelum ransum perlakuan diberikan secara menyeluruh dilakukan pra penyesuaian (preliminary) dimana ransum perlakuan masih dicampur dengan ransum komersial yang pemberiannya secara bertahap sedikit demi sedikit dengan tujuan untuk mencegah terjadinya stress pada saat penggantian ransum perlakuan secara menyeluruh. Ransum perlakuan diberikan pada ayam umur 15-35 hari saat panen. Data diambil pada akhir penelitian dan analisis varian (anova). Apabila perlakuan berpengaruh nyata, akan dilanjutkan dengan uji Beda Nyata Jujur (BNJ). 
Tabel 1. Komposisi Zat Nutrien Dan Energi Metabolis Bahan Penyusun Perlakuan

\begin{tabular}{lcccccc}
\hline Bahan pakan & $\begin{array}{c}\text { Protein } \\
(\%)\end{array}$ & $\begin{array}{c}\text { EM } \\
(\mathrm{kcal} / \mathrm{kg})\end{array}$ & $\begin{array}{c}\text { SK } \\
(\%)\end{array}$ & $\begin{array}{c}\text { Lemak } \\
(\%)\end{array}$ & $\mathrm{Ca}(\%)$ & $\mathrm{P}(\%)$ \\
\hline Kulit kopi jemur* & 7,95 & 2895 & 33,6 & 1,3 & 0,21 & 1,08 \\
Kulit kopi rendam* & 10,55 & 2929 & 32,50 & 0,97 & 0,17 & 2,05 \\
Kulit kopi rebus* & 12,23 & 2764 & 20,60 & 1,28 & 0,26 & 0,88 \\
Jagung ** & 8,42 & 3182 & 2,15 & 5,17 & 0,22 & 0,6 \\
Dedak** & 12,9 & 2875 & 11,4 & 0,7 & 0,07 & 1,5 \\
Konsentrat*** & 38 & 2900 & 6 & 4 & 3 & 1,4 \\
\hline
\end{tabular}

Keterangan: $\mathrm{EM}=$ Energi Metabolis, $\mathrm{SK}=$ Serat Kasar, $\mathrm{Ca}=$ Kalsium, $\mathrm{P}=$ Fosfor

*Hasil Analisa Lab Ilmu dan Teknologi Pakan IPB (2016)

** Hasil Analisa Timbulus et al. (2017)

*** Hasil Analisa PT. Cargil Indonesia

Tabel 2. Susunan Bahan Penyusun Ransum Perlakuan

\begin{tabular}{|c|c|c|c|c|}
\hline Bahan pakan & B1 & $\mathrm{B} 2$ & B3 & B4 \\
\hline Jagung & 40 & 30 & 20 & 10 \\
\hline Kulit kopi (A1/A2/A3) & 0 & 10 & 20 & 30 \\
\hline Konsentrat & 30 & 30 & 30 & 30 \\
\hline Dedak & 29 & 29 & 29 & 29 \\
\hline Mineral & 1 & 1 & 1 & 1 \\
\hline Total & 100 & 100 & 100 & 100 \\
\hline
\end{tabular}

Tabel 3. Komposisi Zat Nutrien dan Energi Metabolis Ransum Perlakuan

\begin{tabular}{cccccccc}
\hline \multirow{2}{*}{ Faktor A } & Faktor B & \multicolumn{7}{c}{ Zat Nutrien } \\
\cline { 3 - 8 } & & $\begin{array}{c}\text { Protein } \\
(\%)\end{array}$ & $\begin{array}{c}\text { EM } \\
(\mathrm{kcal})\end{array}$ & $\begin{array}{c}\text { Serat } \\
\text { Kasar }(\%)\end{array}$ & $\begin{array}{c}\text { Lemak } \\
(\%)\end{array}$ & $\begin{array}{c}\text { Kalsium } \\
(\%)\end{array}$ & $\begin{array}{c}\text { Fosfor } \\
(\%)\end{array}$ \\
\hline \multirow{3}{*}{ A1 } & B0 & 18,50 & 2976,55 & 5,96 & 3,47 & 1,00 & 1,09 \\
& B1 & 18,46 & 2947,85 & 9,11 & 3,08 & 1,00 & 1,14 \\
& B2 & 18,41 & 2919,15 & 12,25 & 2,69 & 1,00 & 1,19 \\
& B3 & 18,36 & 2890,45 & 15,40 & 2,31 & 1,00 & 1,23 \\
& B0 & 18,50 & 2976,55 & 5,96 & 3,47 & 1,00 & 1,09 \\
& B1 & 18,72 & 2951,25 & 9,00 & 3,05 & 1,00 & 1,24 \\
& B2 & 18,93 & 2925,95 & 12,03 & 3,14 & 0,99 & 1,38 \\
& B3 & 19,99 & 2900,65 & 15,07 & 2,21 & 0,99 & 1,53 \\
& A3 & 18,50 & 2976,55 & 5,96 & 3,47 & 1,00 & 1,09 \\
& B1 & 18,89 & 2934,75 & 8,02 & 3,59 & 1,01 & 1,12 \\
& B2 & 19,27 & 2892,95 & 9,65 & 2,69 & 1,01 & 1,15 \\
& B3 & 19,65 & 2851,15 & 11,50 & 2,00 & 1,02 & 1,17 \\
\hline
\end{tabular}

Keterangan: Dihitung berdasarkan Tabel 1 dan 2, A1= Kulit kopi jemur, A2= Kulit Kopi rendam, A3= Kulit kopi rebus, B1= Subtitusi 0\% kulit kopi terhadap jagung, B2= Subtitusi 25\% kulit kopi terhadap jagung, B3= Subtitusi 50\% kulit kopi terhadap jagung, B4= Subtitusi 75\% kulit kopi terhadap jagung. 


\section{Prosedur Pemotongan}

Sebelum dilakukan pemotongan, ayam dipuasakan selama 12 jam dengan tetap diberi air minum. Pemotongan ternak dilakukan berdasarkan cara USDA (United State Departement Of Agriculture, 1997), yaitu dengan memotong Vena jugularis, dan Arteri carotis yang terletak antara tulang kepala dengan ruas tulang leher pertama. Setelah itu ayam digantung dengan posisi kaki berada diatas, kepala di bawah dengan tujuan untuk mempercepat proses penitisan darah setelah ternak dipastikan mati, maka segera direndam ke dalam air hangat dengan suhu 50-55 C selama 90-120 detik untuk memudahkan pencabutan bulu (Soeparno, 2009). Kemudian pengeluaran jeroan, setelah jeroan dikeluarkan dilanjutkan dengan pemisahan bagian-bagian karkas paha, sayap, dada dan punggung.

\section{Variabel}

Persentase potongan karkas diperoleh dengan cara membagi masingmasing potongan komersial karkas dengan berat karkas dikalikan 100\% (Soeparno 2009).

$$
\begin{aligned}
& \% \text { Paha }=\frac{\text { Berat Paha }(\mathrm{g})}{\text { Berat Karkas }(\mathrm{g})} \times 100 \\
& \% \text { Sayap }=\frac{\text { Berat Sayap }(\mathrm{g})}{\text { Berat Karkas }(\mathrm{g})} \times 100
\end{aligned}
$$

$$
\begin{aligned}
& \% \text { Dada }=\frac{\text { Berat Dada }(\mathrm{g})}{\text { Kerat Karkas }(\mathrm{g})} \times 100 \\
& \% \text { Punggung }=\frac{\text { Berat Punggung }(\mathrm{g})}{\text { Berat Karkas }(\mathrm{g})} \times 100
\end{aligned}
$$

\section{HASIL DAN PEMBAHASAN}

Hasil penelitian pengaruh perlakuan terhadap persentase bobot bagian-bagian karkas paha, sayap, dada dan punggung dapat dilihat pada Tabel 4 .

\section{Persentase Bobot Paha}

Hasil analisis keragaman menunjukan bahwa interaksi antara kulit kopi (A) jemur, rendam, rebus dan level substitusi (B) menunjukan hasil yang tidak berbeda nyata $(\mathrm{P}>0,05)$ terhadap persentase bobot paha. Rataan persentase bobot paha pada penelitian ini yaitu 28,92\%-30,98\%. Secara statistik tidak adanya pengaruh perbedaan yang nyata pada persentase bobot paha dalam penelitian ini dikarenakan kandungan protein pada semua ransum perlakuan hampir sama dapat dilihat pada Tabel 3 . Protein berperan penting dalam pertumbuhan otot daging sehingga ransum dengan kandungan protein yang hampir sama akan menghasilkan persentase bobot paha yang tidak jauh berbeda. Menurut Solangi (2003) protein merupakan elemen 
Tabel 4. Rataan Persentase Bobot Bagian-Bagian Karkas

\begin{tabular}{|c|c|c|c|c|c|}
\hline \multirow[t]{2}{*}{ Variabel } & \multirow{2}{*}{$\begin{array}{l}\text { Level } \\
\text { substitusi }\end{array}$} & \multicolumn{3}{|c|}{ Perlakuan } & \multirow[t]{2}{*}{ Rerata } \\
\hline & & A1 & A2 & A3 & \\
\hline \multirow{5}{*}{$\begin{array}{c}\text { Persentase bobot } \\
\text { paha }(\%)\end{array}$} & $\mathrm{B} 0=0 \%$ & $30,38 \pm 3,22$ & $30,38 \pm 3,22$ & $30,38 \pm 3,22$ & $30,38 \pm 0,00$ \\
\hline & $\mathrm{B} 1=25 \%$ & $29,17 \pm 1,52$ & $30,36 \pm 1,51$ & $30,30 \pm 1,81$ & $29,94 \pm 0,67$ \\
\hline & $\mathrm{B} 2=50 \%$ & $28,92 \pm 2,37$ & $29,16 \pm 1,61$ & $28,93 \pm 1,08$ & $29,00 \pm 0,14$ \\
\hline & $\mathrm{B} 3=75 \%$ & $30,21 \pm 2,55$ & $30,38 \pm 2,81$ & $30,98 \pm 1,23$ & $30.52 \pm 0,40$ \\
\hline & Rerata & $29,67 \pm 0,73$ & $30,07 \pm 0,61$ & $\mathbf{3 0}, 15 \pm 0,87$ & \\
\hline \multirow{5}{*}{$\begin{array}{c}\text { Persentase bobot } \\
\text { sayap }(\%)\end{array}$} & $\mathrm{B} 0=0 \%$ & $12,69 \pm 1,57$ & $12,69 \pm 1,57$ & $12,69 \pm 1,57$ & $12,69 \pm 0,00$ \\
\hline & $\mathrm{B} 1=25 \%$ & $10,38 \pm 0,48$ & $10,48 \pm 0,40$ & $12,98 \pm 3,28$ & $11,28 \pm 1,47$ \\
\hline & $\mathrm{B} 2=50 \%$ & $12,26 \pm 1,01$ & $10,94 \pm 0,52$ & $11,76 \pm 0,63$ & $11,65 \pm 0,67$ \\
\hline & $\mathrm{B} 3=75 \%$ & $11,99 \pm 1,03$ & $11,35 \pm 0,97$ & $12,66 \pm 1,04$ & $12,00 \pm 0,66$ \\
\hline & Rerata & $\mathbf{1 1 , 8 3 \pm 1 , 0 1}$ & $11,37 \pm 0,95$ & $12,52 \pm 0,53$ & \\
\hline \multirow{5}{*}{$\begin{array}{c}\text { Persentase bobot } \\
\text { dada }(\%)\end{array}$} & $\mathrm{B} 0=0 \%$ & $35,10 \pm 2,62$ & $35,10 \pm 2,62$ & $35,10 \pm 2,62$ & $35,10 \pm 0,00^{a}$ \\
\hline & $\mathrm{B} 1=25 \%$ & $39,96 \pm 0,36$ & $37,93 \pm 1,83$ & $37,76 \pm 2,00$ & $38,55 \pm 1,22^{c}$ \\
\hline & $\mathrm{B} 2=50 \%$ & $37,48 \pm 3,34$ & $39,63 \pm 0,35$ & $38,30 \pm 1,40$ & $38,47 \pm 1,09^{b c}$ \\
\hline & $\mathrm{B} 3=75 \%$ & $34,61 \pm 2,60$ & $38,14 \pm 5,00$ & $34,16 \pm 1,80$ & $35,64 \pm 2,18^{a b}$ \\
\hline & Rerata & $36,79 \pm 2,46$ & $37,70 \pm 1,89$ & $36,33 \pm 2,01$ & \\
\hline \multirow{5}{*}{$\begin{array}{c}\text { Persentase bobot } \\
\text { punggung }(\%)\end{array}$} & $\mathrm{B} 0=0 \%$ & $21,75 \pm 3,12$ & $21,75 \pm 3,12$ & $21,75 \pm 3,12$ & $21,75 \pm 0,00$ \\
\hline & $\mathrm{B} 1=25 \%$ & $20,16 \pm 0,94$ & $20,82 \pm 1,11$ & $22,71 \pm 6,08$ & $21,23 \pm 1,32$ \\
\hline & $\mathrm{B} 2=50 \%$ & $20,56 \pm 0,62$ & $20,08 \pm 1,63$ & $20,82 \pm 1,91$ & $20,49 \pm 0,38$ \\
\hline & $\mathrm{B} 3=75 \%$ & $22,36 \pm 0,44$ & $19,68 \pm 1,26$ & $21,49 \pm 0,79$ & $21,18 \pm 1,37$ \\
\hline & Rerata & $21,21 \pm 1,02$ & $20,58 \pm 0,91$ & $21,69 \pm 0,78$ & \\
\hline
\end{tabular}

Keterangan: Superskrip huruf berbeda pada kolom yang sama menunjukan berbeda nyata $(\mathrm{P}<0,05)$.

yang sangat penting untuk pertumbuhan otot yang merupakan bagian terbesar dari karkas bagian paha Selain ransum, faktor-faktor yang mempengaruhi persentase karkas ayam pedaging diantaranya jenis ternak, lingkungan, umur dan jenis kelamin (Resnawati, 2010). Persentase karkas ayam jantan berbeda dengan ayam betina sehingga perbedaan ukuran maupun bobot bagianbagian tubuh juga berbeda. Tinggi rendahnya persentase karkas yang dihasilkan akan mempengaruhi persentase bagian-bagian karkas lainnya (Massolo et al., 2017). Menurut Soeparno (2009) menyatakan bahwa bagian persentase paha ayam pedaging $34 \%$ dari bobot karkasnya.

\section{Persentase Bobot Sayap}

Hasil analisis keragaman menunjukan bahwa interaksi antara perlakuan kulit kopi (A) jemur, rendam, rebus dan level substitusi memberikan pengaruh yang tidak berbeda nyata $(\mathrm{P}>0,05)$ terhadap persentase bobot sayap. Rataan persentase bobot sayap dalam penelitian ini yaitu berkisar 10,38\%-12,68\%. Tidak adanya pengaruh penggunaan kulit kopi yang berbeda nyata terhadap persentase 
bobot sayap diduga karena kandungan mineral berupa kalsium dan fosfor pada semua ransum perlakuan hampir sama (Tabel 3). Selain mineral, kandungan protein dan energi dalam ransum penelitian ini juga hampir sama dalam setiap ransum perlakuan dapat dilihat pada (Tabel 3) sehingga menyebabkan persentase bobot sayap juga yang tidak berbeda nyata. Menurut (Nita et al., 2015) bahwa zat-zat makanan berupa protein dan energi serta mineral digunakan untuk pembentukan tulang, daging dan bulu yang didasarkan pada ukuran dan struktur bulu sayap. Tinggi rendahnya persentase sayap juga di dasarkan pada pertumbuhan tulang samakin tinggi bobot tulang sayap semakin tinggi pula persentase sayap begitupun sebaliknya semakin rendah bobot tulang sayap maka semakin rendah pula persentase sayap (Ulupi et al., 2018). Menurut Soeparno (2009) bahwa persentase bobot sayap ayam pedaging yaitu $13 \%$ dari bobot karkasnya.

\section{Persentase Bobot Dada}

Hasil analisis keragaman menunjukan bahwa interaksi antara kulit kopi (A) jemur, rendam, rebus dan level substitusi (B) memberikan pengaruh yang tidak berbeda nyata $(\mathrm{P}>0,05)$. Hasil yang sama juga ditunjukan oleh metode pengolahan kulit kopi (A) terhadap persentase bobot dada. Hal ini menunjukan bahwa dijemur, direndam dan direbus tidak memberikan pengaruh. Hasil yang berbeda ditunjukan oleh perlakuan level substitusi memberikan pengaruh yang berbeda nyata $(\mathrm{P}<0,05)$ terhadap persentase bobot dada. Uji lanjut BNJ persentase bobot dada pada level substitusi menunjukan bahwa perlakuan B0 berbeda nyata $(\mathrm{P}<0,05)$ dengan B1 dan beda nyata lebih kecil dengan B2 tetapi tidak berbeda nyata $(\mathrm{P}>0,05)$ dengan $\mathrm{B} 3$, sedangkan $\mathrm{B} 1$ berbeda nyata $(\mathrm{P}<0,05)$ dengan B3. Rataan persentase terendah yaitu pada ransum kontrol tanpa kulit kopi B0 dengan rataan $30,10 \%$ dari bobot karkas sedangkan rataan persentase bobot dada tertinggi yaitu pada ransum level substitusi $25 \%$ kulit kopi terhadap jagung (B1) dengan rataan sebesar $38,55 \%$ dari bobot karkas. Hal ini menandakan bahwa penggunaan kulit kopi pada level substitusi $25 \%$ menggantikan jagung dapat meningkatkan persentase bagian dada ayam pedaging. Persentase dada pada level substitusi 25\% (B1) kulit kopi terhadap jagung juga lebih tinggi dibandingkan dengan ransum kontrol tanpa kulit kopi yaitu B0 dengan rataan persentase $35,10 \%$. Peningkatan bobot dada pada level substitusi $25 \%$ kulit kopi terhadap jagung diduga karena serat kasar dalam ransum kulit kopi jemur, rendam dan rebus pada level substitusi 25\% lebih rendah jika dibandingkan dengan level substitusi 50\% dan $75 \%$. Pada Tabel 3 dapat dilihat bahwa semakin meningkat level substitusi semakin 
meningkat pula serat kasar. Sedangkan pada Tabel 4 semakin tinggi level substitusi semakin rendah persentase dada begitupun sebaliknya semakin rendah level substitusi maka semakin tinggi persentase dada. Serat kasar dalam ransum dapat mempengaruhi tinggi rendanya persentase bagian karkas sehingga perbedaan yang signifikan akan terlihat dari level substitusi yang paling tinggi dengan yang paling rendah. Kandungan serat kasar yang tinggi serta adanya zat anti nutrisi seperti tanin dan kafein menjadi faktor pembatas penggunaan kulit kopi (Akmal dan Filawati, 2008). Dalam keadaan normal, dengan kondisi lingkungan yang baik persentase dada berkisar 35\% (Tatli et al., 2008).

\section{Persentase Bobot Punggung}

Hasil analisis ragam menunjukan bahwa interaksi antara perlakuan kulit kopi (A) dijemur, rendam, rebus (A3) dan level substitusi memberikan pengaruh yang tidak berbeda nyata $(\mathrm{P}>0,05)$ terhadap persentase bobot punggung hal ini disebabkan karena kandungan mineral yang ada dalam setiap ransum perlakuan hampir sama baik dalam ransum kulit kopi jemur, rendam dan rebus sehingga bagian tubuh yang tersusun atas komponen lebih banyak tulang seperti sayap dan punggung tidak berbeda nyata. Hasil penelitian menunjukan bahwa rataan persentase bobot punggung dalam penelitian ini yaitu 19,68\%-22,71\%. Menurut
(Marfuah, 2016) persentase punggung ayam broiler umur 6 minggu berkisar antara 21,36 $-22,31 \%$ dari bobot karkasnya.

\section{KESIMPULAN}

Dari hasil penelitian dapat disimpulkan bahwa penggunaan kulit kopi $25 \%$ menggantikan sebagian jagung memberikan hasil terbaik terhadap persentase bobot bagian-bagian karkas ayam pedaging pada semua metode pengolahan.

\section{DAFTAR PUSTAKA}

Akmal dan Filawati. 2008. Pemanfaatan Kapang aspergillis niger sebagai inokulan fermentasi kulit kopi dengan media cair dan pengaruhnya terhadap performans ayam broiler. Jurnal Ilmu-Ilmu Peternakan. Vol. 11(3):150-158.

Badan Standarisasi Nasional. 2009 Mutu Karkas dan Daging Ayam. Badan Standarisasi Nasional. Jakarta.

Marfuah, N. 2016. Kadar kolesterol daging dan kualitas karkas ayam pedaging dengan penggunaan tepung bawang putih dalam ransum. J. Agrisains Vol 17(3) :116-122.

Massolo, R., A. Mujnisa dan L. Agustina. 2017. Persentase karkas dan lemak abdominal broiler yang diberi prebiotik inulin umbi bunga dahlia (Dahlia variabillis). Buletin Nutrisi dan Makanan Ternak 12(2): 50-58.

Mayasari, N. 2009. Pengaruh Penambahan Kulit Buah Kopi Robusta (coffea 
canephora) Produk Fermentasi Jamur Tiram putih (Pleurotus ostreatus) Dalam Ransum Terhadap Konsentrasi VFH dan NH3 (In Vitro). Bandung: KPP Ilmu Hayati. LPPM ITB.

Nathanael, A., D. Sunarti, dan W. Sarengat. 2015. Pengaruh penggunaan tepung daun katuk (Sauropus androgynus) dalam ransum terhadap persentase potongan komersial karkas, kulit dan meat bone ratio ayam broiler. Animal Agriculture Journal 4(2):190-194.

Nita, N.S., E. Dihansih dan Anggraeni. 2015. Pengaruh pemberian kadar protein pakan yang berbeda terhadap bobot komponen karkas dan nonkarkas ayam jantan petelur. Jurnal Peternakan Nusantara 1(2):2442-2541.

Noferdiman. 2009. Pengaruh penggunaan lumpur sawit fermentasi dengan jamur P.chrysosporium dalam ransum terhadap performans ayam broiler. Jurnal Ilmiah Ilmu-ilmu Peternakan 12(4): 176-185.

Resnawati, H. 2010. Bobot organ-organ tubuh pada ayam pedaging yang diberi pakan mengandung minyak biji saga (Adenanthera pavoninal). Prosiding. Seminar Nasional Teknologi Peternakan dan Veteriner. 670-673.

Sarikhan, M., H.A. Shahryar, B. Gholizadeh, M.H. Hosseinzadeh, B. Beheshti, and A. Mahmoodnejad. 2010. Effects of insoluble fiber on growth performence, carcass traits and ileum morphological parameters on broiler chick males. Int J Agic Biol. 12(4): 531-536.
Soeparno. 2009. Ilmu dan Teknologi Daging. Cetakan kelima. Gadjah Mada University Press: Yogyakarta.

Solangi, A.A., Baloch G. M., Wagan P. K., Chachar B. And Memon A. 2003. Effect of different level of dietary protein on growth of broiler. Journal Of Animal And Veterinary Advances 2(5): 301-304.

Steel R. G. D., and J. H. Torrie. 1980. Principles and Procedures of Statistics A Biometrical Approach. Second Edition. Mc Graw-Hill International Book Company. Tokyo. Page 633.

Tatli P, Seven I, Yilmaz M, Simsek UG. 2008. The Effect of Turkish propolis on growth and carcass characteristics in broiler under heat stress. Anim Feed Sci Technol. 146(1):137-148.

Timbulus, C.M, P.R.R.I. Montong, A. Dp. Mirah, S. E. Siswosubroto. 2017 Penampilan produksi ternak babi grower yang menggunakan tepung kulit kopi sebagai bahan pengganti sebagian dedak halus pada pakan Jurnal Zootek 37(2): 242-251.

Ulupi, N., H. Nuraini, J. Parulian dan S. Q. Kusuma. 2018. Karakteristik karkas dan non karkas ayam broiler jantan dan betina pada umur pemotongan 30 hari. Jurnal Ilmu Produksi dan dan Teknologi Hasil Peternakan 6(1): 1-5.

USDA. 1997. Poultry Grading Manual. Agriculture Hand Book No. 30 U.S Department of Agriculture dalam Jurnal Peternakan Tropika 4(1): 184-195.

Uzer, F., N. Iriyanti dan Roesdiyanto. 2013. Penggunaan pakan fungsional 
dalam ransum terhadap konsumsi pakan dan pertambahan bobot badan ayam broiler. Jurnal Ilmiah Peternakan 1(1): 282-288.

Yuniastuti, A. 2002. Efek pakan berserat pada ransum ayam terhadap kadar lemak dan kolestrol daging ayam broiler. Jurnal Ilmiah Sainteks, Vol 9 (3): 175. 